\title{
Sex Determination of Japanese Quails (Coturnix Coturnix Japonica) using with Zoometric Measurements
}

\author{
Tülin Çiçek Rathert ${ }^{1 *}$ İnan Güven ${ }^{1}$, Fatih Üçkardeş ${ }^{2}$
}

${ }^{\text {I} D e p a r t m e n t ~ o f ~ A n i m a l ~ P r o d u c t i o n, ~ F a c u l t y ~ o f ~ A g r i c u l t u r e, ~ K a h r a m a n m a r a s ̧ ~ S u ̈ t c ̧ u ̈ ~ I ̇ m a m ~ U n i v e r s i t y, ~} 46050$ Kahramanmaraş, Turkey ${ }^{2}$ Department of Biostatistics and Medical Informatics, Basic Medical Sciences, Adiyaman University, 02040 Adiyaman, Turkey AR T ICLE IN F O A B S T R A C T

Research Article

Received 18 April 2017 Accepted 17 June 2017

Keywords:

Japanese quail

Sex discrimination

Zoometric measurement

Body traits

Poultry production

\author{
*Corresponding Author: \\ E-mail: tuci@ksu.edu.tr
}

\begin{abstract}
The difficulty of sex determination in most poultry species causes significant financial losses for poultry production as birds cannot be separated at early stages of growth for meat or egg production. Therefore it is important to determine bird's sex with zoometric parameters. This study was carried out to determine the sex of Japanese quails with zoometric measurements, such as live weight, body length, chest depth and chest width. Eighty-eight male and female Japanese quail chicks were used individually for live weight, chest depth $(\mathrm{mm})$, chest width $(\mathrm{mm})$ and body length $(\mathrm{mm})$ with using digital scaled balance and caliper for every week over a period of six weeks. The weekly collected data were applied to t test for estimating the sex discrimination. The Pearson's correlation was applied for examining the interrelationship between sex and biometric traits. The results indicated that there was a significant positive correlation between live weight and body length beginning with the $2^{\text {nd }}$ week. Therefore, zoometric measurement of these body traits is suitable for discriminating the sex of Japanese quails in early phase of life.
\end{abstract}

DOI: https://doi.org/10.24925/turjaf.v5i9.1002-1005.1278

\section{Introduction}

Quails participate an important role in poultry production as meat and egg production. The human tendency to consume protein coming from animals has made quail production even more important (Balcıoğlu et al., 2005). Factors, such as a short generation interval, suitability for genetic improvement, the facts that the birds cover a small space and consume a small amount of feed have led to a frequent use of quails for breeding purposes (Koçak and Özkan, 2000). Japan and China are the countries which are leading in studies on genetic selection in order to make more use of quail meat and eggs (Nazligül et al., 2001). Japanese quails, which belong to the pheasant family Phasianidae, were first intensively produced in Japan in the 1920s. While quail breeding for egg production has been continued in that part of the world, it was continued particularly in Spain and France for meat production.

At an early age, gender determination according to the morphological characteristics of Japanese quail is not easy. After hatching, live weight increases continuously up to puberty. The sexual maturity of Japanese quails lasts 4-6 weeks. In female birds the increase in live weight goes on until the $6^{\text {th }}$ week of age and they generally start laying eggs during this period (Alkan et al., 2008b). For this reason, the first six weeks are critical in order to determine values indicating information about certain yield traits (Cerit and Altınel, 1998). Although it is easier to discriminate the sex from the $6^{\text {th }}$ week of age due to the larger body shape of female birds as well as through observing typical behaviour of male birds (Brunström et al., 2009). This is too late since quails reach a weight suitable for sales markets after 5-6 weeks. Female birds have a higher live weight than male ones. However, the carcass rate of male birds is higher. This is because liver, digestive tract and genital system are lighter. It is commonly known that zoometrical body measurements show different results between the sexes. It is therefore possible to determine the sex of a bird in early weeks through zoometrical body measurements. In this study some important relations between sex and several body measurements are reported. The most important of these are wing length and live weight in female quails and chest width instead of wing length in male quails (Genç et al., 2009).

Discrimination of sex in poultry is done using different methods such as examining of feet, neck, feather colour and length as well as cloaca control, radiographic examination, footprint and hormonal or operational methods (Cerit and Avanus, 2007).Besides its importance for behavioural studies and wildlife management (Henry et al., 2015; Volodin et al., 2015), determination of sex is crucial for the profitability of agribusinesses. Zoometric 
measurement as a tool in sex discrimination has been examined in, for instance, mockingbirds (Fuchs and Montalti, 2016), owls (Tornberg et al., 2016), coots (Minias, 2015), Muscovy ducks (Oguntunji and Ayorinde, 2014) showing rather inconclusive results concerning predictability in terms of species and measurements traits.

It is of advantage that there are specific differences between the sexes in quails. These differences can be determined at a rate of $99 \%$ in one-day chicks. A deep rugae, a remarkable protrusion or a cavity at the edge of the dorsal cloaca are characteristic features of male birds. This characteristic is typically well developed in male birds. The colouring of the chest feathers in the $2^{\text {nd }}$ and $3^{\text {rd }}$ week of age is also a reliable indicator for sex discrimination. Spotted and reddish-brown feathers start sprouting in this period. From approximately the $6^{\text {th }}$ week on the large body shape of female birds and distinct behaviour of male birds can be recognized. During this period the production of cloacal foam can be observed in male quails (Tservem Gouss and Yannakopoulos, 1986). These methods in discriminating the sex of quails are impractical for agricultural businesses due to expenditure and the need of qualified staff. It is therefore necessary to use alternative methods in discriminating the sex.

This study aims to assess the feasibility of using data of live weight, chest width, chest depth and body length in the first six weeks of age in order to discriminate the sex of Japanese quails. To the best of our knowledge there is no study explicitly examining the feasibility of using zoometric measurements to identify sex in quails.

\section{Material and Method}

88 Japanese quails (day old) were used in this 6-week study. The birds were held in battery cages without separating the female birds from the male ones. In the first week 23 hours illuminating was applied, after that 16 hours. The basal diet, which contained $20 \%$ raw protein and $2900 \mathrm{kcal}$ metabolizable energy, was given ad libitum (Table 1).

The animal were individually weighed every week with a scale accurate to $0.1 \mathrm{~g}$ over a period of 6 weeks. Head girth (the distance between left and right eye known as fibrous ring), body, length, beak (from apex to the end of os incisivum), wing length, body (the distance between near end of Ingluvies and distal end of cloaca), chest length (the distance between os sternum proximal and the distal end), chest breadth (bilateral, between both ends of Articulatio humeri) and metatarsus length (lower leg between the two joints). Chest circumference (radius covering Costalar sternum proximal and scapula) were conducted with a tape measure (Wickel et al., 1977).

The obtained data were classified according to sexual factors and then processed statistically. $\mathrm{T}$ test was undergone on two independent samples in order to determine differences between weekly body measurements aimed at discriminating the sex of the quails. Pearson correlation test was used to reveal relations of body characteristics according to sex. The data were evaluated with SPSS 15.0 (2006).
Table 1 Calculated values of the ration (\%)

\begin{tabular}{l|c}
\hline \multicolumn{1}{c|}{ Nutrients } & Amount (\%) \\
\hline Raw Protein & 20 \\
Raw Cellulose & 6 \\
Raw Cinder & 11 \\
Solved Cinder in HCL & 1 \\
Calcium & $2,5-4$ \\
Total Phosphor & 0.60 \\
Sodium & $0.10-0.30$ \\
NaCI (Salt) & 0.30 \\
Lysine & 1.1 \\
Methionine & 0.44 \\
Cystine & 0.84 \\
\hline
\end{tabular}

\section{Results}

The weekly averages for the individual male and female body characteristics are given in Table 2 . In week 1 there was no difference between the male and female quails in body measurements $(\mathrm{P}>0.05)$. In week 2 there was a highly significant difference in live weight and body length between female and male quails $(\mathrm{P}<0.01)$. According to these results both live weight and body length are higher in female than in male quails. In week 3 the same characteristics were found significant $(\mathrm{P}>0.05)$. In weeks 2 and 3 there was a difference in chest width and chest depth between the sexes $(\mathrm{P}>0.05)$. Although the body measurements for female birds were higher than those for male birds in week 4, these differences were statistically not significant $(\mathrm{P}>0.05)$. In week 5 live weight and body length were higher in female than in male birds and these differences were significant $(\mathrm{P}<0.05)$. Differences in chest width and chest depth, however, were not significant $(\mathrm{P}>0.05)$. As in the previous weeks live weight $(\mathrm{P}<0.05)$, body length and chest width $(\mathrm{P}<0.01)$ in female birds were higher than in male birds. The difference in chest depth, however, was found to be not significant $(\mathrm{P}>0.05)$.

The correlation values for live weight and the other body measurements are given in Table 3 . In week 1 the correlations between live weight and chest depth (33.9 $\%$ ), body length and chest width (50.9\%) and between chest width and chest depth $(39.1 \%)$ in male quails were statistically significant $(\mathrm{P}<0.05)$. The correlations between live weight and body length, between live weight and chest width and between body length and chest depth were not significant $(\mathrm{P}>0.05)$. All correlations between body traits in female quails were highly significant $(\mathrm{P}<0.01)$.

Differently from week 1, all the correlations between zoometric body measurements in female quails were highly significant $(\mathrm{P}<0.01)$, while in male birds the correlations between live weight and body length (32.6 $\%$ ), body length and chest depth $(31.0 \%)$ and between chest width and chest depth (57.8\%) showed the same levels of significance $(\mathrm{P}<0.05 ; \mathrm{P}<0.01)$ as it was the case in week 1 . The correlations between live weight and chest width, live weight and chest depth as well as body length and chest width were statistically not significant. 
Table 2. Changes of zoometric body measurements in Japanese quails according to sex

\begin{tabular}{|c|c|c|c|c|c|c|c|c|}
\hline \multirow{2}{*}{ Traits } & \multirow{2}{*}{ Sex } & \multirow{2}{*}{$\mathrm{N}$} & \multicolumn{6}{|c|}{ Week \pm Standard Deviation } \\
\hline & & & 1 & 2 & 3 & 4 & 5 & 6 \\
\hline \multirow{3}{*}{ Live Weight } & $\mathrm{F}$ & 43 & $19.74 \pm 0.507$ & $52.11 \pm 0.892$ & $88.31 \pm 1.883$ & $135.28 \pm 2.022$ & $145.81 \pm 4.160$ & $182.00 \pm 4.218$ \\
\hline & M & 45 & $19.91 \pm 0.499$ & $47.46 \pm 1.278$ & $82.41 \pm 1.933$ & $130.85 \pm 2.045$ & $133.12 \pm 3.572$ & $166.23 \pm 4.468$ \\
\hline & & & 0.810 & 0.004 & 0.032 & 0.127 & 0.023 & 0.012 \\
\hline \multirow{3}{*}{$\begin{array}{l}\text { Body } \\
\text { Length }\end{array}$} & $\mathrm{F}$ & 43 & $25.79 \pm 0.461$ & $34.71 \pm 0.374$ & $45.92 \pm 0.466$ & $51.03 \pm 0.525$ & $53.69 \pm 0.562$ & $59.56 \pm 0.428$ \\
\hline & M & 45 & $24.93 \pm 0.404$ & $33.13 \pm 0.448$ & $44.52 \pm 0.524$ & $50.77 \pm 0.607$ & $51.96 \pm 0.536$ & $57.35 \pm 0.444$ \\
\hline & & & 0.164 & 0.008 & 0.050 & 0.746 & 0.029 & 0.001 \\
\hline \multirow{3}{*}{ Chest Width } & $\mathrm{F}$ & 43 & $15.72 \pm 0.368$ & $23.45 \pm 0.370$ & $27.91 \pm 0.401$ & $31.19 \pm 0.593$ & $33.53 \pm 0.478$ & $36.68 \pm 0.515$ \\
\hline & M & 45 & $15.60 \pm 0.292$ & $23.23 \pm 0.391$ & $27.53 \pm 0.421$ & $30.97 \pm 0.610$ & $32.55 \pm 0.646$ & $34.76 \pm 0.422$ \\
\hline & & & 0.797 & 0.693 & 0.523 & 0.791 & 0.230 & 0.005 \\
\hline \multirow{3}{*}{ Chest Depth } & $\mathrm{F}$ & 43 & $22.35 \pm 0.391$ & $34.57 \pm 0.492$ & $39.41 \pm 0.401$ & $45.33 \pm 0.588$ & $50.31 \pm 0.512$ & $52.83 \pm 0.419$ \\
\hline & M & 45 & $22.24 \pm 0.329$ & $34.96 \pm 0.472$ & $39.03 \pm 0.421$ & $44.92 \pm 0.619$ & $49.07 \pm 0.489$ & $51.88 \pm 0.627$ \\
\hline & & & 0.838 & 0.567 & 0.523 & 0.634 & 0.083 & 0.216 \\
\hline
\end{tabular}

Table 3 Correlation of body characteristics among individual male birds and among female birds for each week

\begin{tabular}{|c|c|c|c|c|c|c|}
\hline Weeks & \multicolumn{3}{|c|}{ Male } & \multicolumn{3}{|c|}{ Female } \\
\hline 1st Week & $\mathrm{BL}$ & $\mathrm{CW}$ & $\mathrm{CD}$ & $\overline{B L}$ & $\mathrm{CW}$ & $\mathrm{CD}$ \\
\hline LW & 0.241 & 0.122 & $0.339 *$ & $0.499 * *$ & $0.452 * *$ & $0.525 * *$ \\
\hline $\mathrm{BL}$ & & $0.509 * *$ & 0.155 & & $0.612 * *$ & $0.511 * *$ \\
\hline $\mathrm{CW}$ & & & $0.391 * *$ & & & $0.648 * *$ \\
\hline 2nd Week & & & & & & \\
\hline LW & $0.581 * *$ & $0.417 * *$ & $0.719 * *$ & $0.326^{*}$ & 0.221 & 0.298 \\
\hline BL & & $0.446^{* *}$ & $0.471 * *$ & & 0.292 & $0.310^{*}$ \\
\hline $\mathrm{CW}$ & & & $0.469 * *$ & & & $0.578 * *$ \\
\hline 3rd Week & & & & & & \\
\hline LW & $0.763 * *$ & $0.717 * *$ & $0.717 * *$ & $0.524 * *$ & $0.562 * *$ & $0.562 * *$ \\
\hline $\mathrm{BL}$ & & $0.626 * *$ & $0.626 * *$ & & $0.510 * *$ & $0.510 * *$ \\
\hline $\mathrm{CW}$ & & & $1.000 * *$ & & & $1.000 * *$ \\
\hline 4th Week & & & & & & \\
\hline LW & $0.695 * *$ & $0.641 * *$ & $0.649 * *$ & $0.525 * *$ & $0.558 * *$ & $0.520 * *$ \\
\hline BL & & $0.966 * *$ & $0.965 * *$ & & $0.870 * *$ & $0.939 * *$ \\
\hline $\mathrm{CW}$ & & & $0.962 * *$ & & & $0.760 * *$ \\
\hline 5th Week & & & & & & \\
\hline LW & $0.540 * *$ & $0.545 * *$ & $0.787 * *$ & $0.620 * *$ & $0.615 * *$ & $0.848 * *$ \\
\hline $\mathrm{BL}$ & & $0.505 * *$ & $0.689 * *$ & & $0.686 * *$ & $0.624 * *$ \\
\hline CW & & & $0.392 * *$ & & & $0.708 * *$ \\
\hline 6th Week & & & & & & \\
\hline LW & $0.667 * *$ & $0.778 * *$ & $0.541 * *$ & $0.634 * *$ & $0.526 * *$ & $0.650 * *$ \\
\hline $\mathrm{BL}$ & & $0.553 * *$ & $0.465 * *$ & & $0.534 * *$ & $0.356^{*}$ \\
\hline $\mathrm{CW}$ & & & $0.549 * *$ & & & $0.481 * *$ \\
\hline
\end{tabular}

In week 3 the correlation between zoometric body measurements were highly significant $(\mathrm{P}<0.01)$ in either sex. Moreover, there was a hundred per cent congruence between the sexes in the correlation between chest width and chest depth. The correlations of the other body measurements were above medium-level.

In week 4 correlations between body traits were found highly significant in both male and female quails. $(\mathrm{P}<0.01)$. Total congruence in some trait correlations between individual birds of the same sex was determined. In male birds, the correlations between body length and chest width (96.6\%), body length and chest depth (96.5\%) and chest width and chest depth (96.6\%) showed congruence. This was the case in female birds for the correlations between body length and chest width (87\%) and body length and chest depth (93.9\%). The correlations between the other body characteristics were above medium level.

In week 5 the correlations between body characteristics of male and those of female birds were highly significant $(\mathrm{P}<0.01)$. There was, however a decrease in correlations between body characteristics which were congruent in weeks 3 and 4 .

In week 6 the correlations between body characteristics of male and those of female birds were highly significant $(\mathrm{P}<0.01)$. The correlation between body length and chest depth in female birds, however, was less significant compared to the other values. The correlation of body characteristics between individual male birds and those between male individual birds were found to be at mediate level. 


\section{Discussion}

The current study aimed to evaluate the feasibility of using zoometric measurements to discriminate sex in Japanese quails. The results suggest that feasibility depends on both the traits measured and the time (in weeks of age) of measurement. This general result indicates that different morphological measurements display different discriminating power as observed in other studies (see, for example Yakubu, (2011), for Muscovy ducks; Perkins et al., (2009), for clapper rails and king rails).

In the case of Japanese quails, live weight and body length are critical from week 2 on for discriminating the sex. Equivalent to this study, the study by Alkan et al. (2008a) has shown the significance of live weight for discriminating the sex of Japanese quails from week 2 on in a 6 -week breeding period. Another study dealing with the effects of live weight and certain body characteristics on sexual factors found the effects of live weight and body length significant (Genç et al., 2009). In this context it is worth reporting the effect of high live weight on the quality of sperm and an early beginning of the egg laying period (Türkmut et al., 1999). There is a strong probability that birds which have a high live weight and body length from week 2 on are female. For this reason live weight and body length are particularly suitable for presuming the sex of Japanese quails in a selection at an early stage. Although in this study live weight and body length were high particularly in week 4 , the difference of these traits between the sexes was statistically not significant; this emphasises the importance of the recording of live weight and body length in the first weeks as a criteria for sex discrimination.

The first six weeks of age are of highly important for both laying quails and broiler quails. A discrimination of the sex helps decide towards what yield the flock is going to be bred. Sex discrimination in large flocks, however, is connected to high expenditure of time and work. It is therefore preferable to use zoometric measurements of live weight and body length since high values of these traits suggest strongly that the birds are female even though they do not give absolute certainty. In line with other studies on different poultry species (Oguntunji and Ayorinde, 2014; Minias, 2015) this study suggests that sex discrimination in poultry through zoometric measurements may be a viable alternative to examining the protrusion at the edge of the dorsal cloaca in quail.

Given the potential benefits of zoometrical measurements for the understanding of ecological aspects and in management (Ruckstuhl and Clutton-Brock, 2005; Dechaume-Moncharmont et al., 2011) and accepting it as a method that is less invasive, relatively inexpensive and conducing to sex determination in birds (Montalti et al., 2012) further research, however, is indicated to test the applicability of this method.

\section{References}

Alkan S, Galiç A, Karabağ K, Balcıŏglu MS. 2008a. Japon Bildırcınlarında (Coturnix coturnix japonica) Canlı Ağırlık ve Yumurta Verimi Bakımından Seleksiyonun Çıkış ve 6. Hafta Canlı Ağırlıklarına Etkileri. Hayvansal Üretim, 49 (1): 16-19.
Alkan S, Karabağ K, Galiç A, Karslı T. 2008b. Effects of Genotype and Body Weight on Egg Production and Feed Consumption in Japanese Quails (Coturnix Coturnix Japonica) in winter season reared in Antalya Region. Lalahan Hay. Araşt. Enst. Derg., 48 (2): $73-79$.

Balcığlu, MS, Yolcu H, Firat M, Karabağ K, Şahin E. 2005. Estimation of Genetics Parameters for Liveweights and Liveweight Gain in Japanese Quail. Mediterr. Agric. Sci., 18(1): 35-39.

Brunström B, Axelsson J, Mattsson A, Haldin K. 2009. Effects of Strogens on Sex Differentiation in Japonse Quail and Chicken. Gen Comp. Endocrinol., 163: 97-103.

Cerit H, Altınel A. 1998. Japon Bıldırcınlarının (Coturnixcoturnix japonica) Çeşitli Verim Özelliklerine Ait Genetik ve Fenotipik Parametreler. İstanbul Univ. Vet. Fak. Derg., 24 (1): 111-136.

Cerit H, Avanus K. 2007. Sex Identification in Avian Species Using DNA Typing Methods. Worlds Poult. Sci. J., 63:91-99.

Dechaume-Moncharmont FX, Monceau K, Cezilly F. 2011. Sexing birds using discriminant function analysis: A critical appraisal. The Auk., 128(1): 78-86.

Fuchs DV, Montalti D. 2016. Do morphometric measurements allow sex discrimination in mockingbirds (Mimus sp)? All Res. J. Biol., 3(7): 34-40.

Genç S, Gürcan EK, Önal AR, Erbaş C. 2009. Bıldırcınlarda Cinsiyet Faktörünün Canlı Ağırlık ve Çeşitli Vücut Ölçüleri Üzerine Etkisinin Çok Değişkenli Varyans Analizi Yöntemleri ile Belirlenmesi. 5. Ulusal Zootekni Öğrenci Kongresi, Tokat:54.

Henry L, Biquand V, Craig AJFK Hausberger M, 2015. Sexing adult pale winged starlings using morphometric and discriminant function analysis. PLoS ONE, 10(9): e0135628. doi:10.1371/journal.pone.0135628

Koçak Ç, Özkan S. 2000. Bıldırcın, sülün ve keklik yetiştiriciliği. Ege Üniversitesi Ziraat Fakültesi Yayın No:538.

Minias P. 2015. Sex determination of adult Eurasian coots (Fulica atra) by morphometric measurements. Waterbirds, 38(2): 191-194.

Montalti D, Graña Grilli M, Maragliano RE, Cassini G. 2012. The reliability of morphometric discriminant functions in determining the sex of Chileanflamingos Phoenicopterus chilensis. Curr. Zool., 58: 851-855.

Nazlıgül A, Bardakçıŏlu HE, Türkyılmaz K, Cenan N, Oral D. 2001. The effect of cage density on egg weight, egg production and feed consumption in Japanese quails. İstanbul Univ. Vet. Fak. Derg., 27 (2): 429-438.

Oguntunji AO, Ayorinde KL. 2014. Sexual size dimorphism and sex determination by morphometric measurements in locally adapted Muscovy duck (Cairina moschata) in Nigeria. Acta. Agric. Slov., 104 (1): 15-24. DOI:10.14720/aas.2014.104.1.2

Perkins M, King SM, Travis SE, Linscombe J. 2009. Use of Morphometric Measurements to Differentiate between Species and Sex of King and Clapper Rails. Waterbirds, 32(4): 579-584.

Ruckstuhl, KE, Clutton-Brock TH. 2005. Sexual segregation and the ecology of the two sexes. Published by Cambridge University Press. Cambridge. ISBN-13: 9780521835220

SPSS: SPSS Professional Statistics 15.0, SPSS Inc, Chicago, 2006.

Tornberg R, Mikkoa H, Rytkönen S. 2016. Morphometric sex determination of great grey owls Strix nebulosi. Ornis. Norv., 39: 6-10.

Tservem Gouss, AS, Yannakopoulos AL. 1986. Carcass Characteristics of Japonese Quail at 42 Days of Age. Br. Poult. Sci., 27(1): 123-127.

Türkmut L, Altan Ö, Oğuz İ, Yalçın S. 1999.Effects of Selection of Four Week Body Weight on Reproductive Performance in Japanese Quail. Turk. J. Vet. Anim. Sci., 23: 229-234.

Volodin IA, Volodina EV, Klenova AV, Matrosova VA. 2015. Gender identification using acoustic analysis in birds without external sexual dimorphism. Avain Res., 6-20. DOI: 10.1186/s40657-015-0033-y

Yakubu A. 2011. Discriminant analysis of sexual dimorphismin morphological traits of African Muscovy ducks. Arch. Zootec., 60 (232): 1115-1123. 